\title{
Continuous citric acid secretion by a high specific pH dependent active transport system in yeast Candida oleophila ATCC 20177
}

\author{
Savas Anastassiadis* \\ Department of Environmental Engineering \\ School of Engineering \\ Democritus University of Thrace \\ 67100 Xanthi, Greece \\ E-mail: sanasta@env.duth.gr \\ Hans-Jürgen Rehm \\ Institute of Microbiology \\ University of Münster \\ Corrensstr. 3, 48149 Münster, Germany \\ (retired Professor) \\ Website: http://www.greekbiotechnologycenter.gr
}

Financial support: Part of the work that has been carried out at the Institute of Biotechnology 2 of Research Centre Jülich (Germany) was financed by Haarmann and Reimer, a daughter company of the company Bayer, Leverkusen, Germany.

Keywords: active citrate export, citric acid fermentation, energy consuming citric acid secretion, specific active transport system.

Present address: "Research in Biotechnology, Co., Vat. \#: 108851559. Avgi/Sohos, 57002 Thessaloniki, Greece; Tel. +30-2395-051324; +30-6973801395 (cellular); Tel./Fax.+30-2395-051470, E-mail: sanastassiadis@netscape.net.

The $\mathbf{p H}$ influence on continuous citric acid secretion was investigated in Candida oleophila ATCC 20177 (var.) under $\mathrm{NH}_{4}^{+}$limiting state steady conditions, using glucose. Highest citric acid concentration of $57.8 \mathrm{~g} / \mathrm{l}$, citrate/isocitrate ratio of 15.6 , space-time yield of 0.96 $\mathrm{g} /(\mathbf{l} \mathrm{x} \mathrm{hr})$ and biomass specific productivity of $0.041 \mathrm{~g} /(\mathrm{g}$ $\mathrm{x}$ hr) were obtained at $\mathrm{pH} 5$ and $60 \mathrm{hrs}$ residence time. Only $22.8 \mathrm{~g} / \mathrm{l}(39.4 \%)$ and a ratio of 9.9 were achieved at pH $6 \mathrm{pH}$ and $12.4 \mathrm{~g} / \mathrm{l}(21.5 \%)$ and a ratio of 3.7 at $\mathrm{pH} 3$. Under non producing conditions, in excess of nitrogen, biomass concentration increased at raising $\mathrm{pH}$. An iron concentration of $200 \mathrm{ppm}$ was determined in biomass of C. oleophila at pH 5, compared with only $26 \mathrm{ppm}$ found at pH 3 (factor 7.7). Intra- and extracellular concentrations of citrates and glucose confirmed the existence of a high specific, $\mathrm{pH}$ dependent active transport system for citrate secretion, while isocitrate isn't a high-affine substrate, displaying a strong correlation with ATP/ADP ratio. Differences between extra- and intracellular concentration of citrate higher than 1 and up to about 60 were determined. The active transport systemfor citrate excretion appears to be the main speed-determining factor in citrate overproduction by yeasts.

Although citric acid production using mutant strains of $A$. niger or yeast strains has almost been extensively optimised, there is still no comprehensive explanation for citrate overproduction, and many aspects related to citrate accumulation and secretion remain unclear. There are many similarities between $A$. niger and yeast strains in mechanism of citric acid synthesis, however, differences still exist in terms of triggering out and regulation of citrate overproduction. Many models have been developed describing the biochemistry of citrate synthesis, using glucose and other carbon sources, however a complete picture of formation pathway, regulation and secretion has not been described.

Overproduction of citric acid in moulds and yeast has been reported to be triggered out by limitations of certain elements, like N, P, Mn, Fe or Zn, essential for citrate accumulation in A. niger (Shu and Johnson, 1948a; Shu and Johnson, 1948b; Noguchi and Johnson, 1961; Kisser et al. 1980; Kubicek and Röhr, 1980; Kapoor et al. 1982; Kristiansen et al. 1982; Crueger and Crueger, 1989; Dawson and Maddox, 1989; Grewal and Kalra, 1995), as well as N, P, S and Mg in yeasts Yarrowia lipolytica and Candida oleophila (Lozinov et al. 1974; Behrens et al. 1987; Stottmeister and Hoppe, 1991; Anastassiadis, 1994; Anastassiadis et al. 2001; Anastassiadis et al. 2002; Anastassiadis et al. 2004). The yeasts can use various carbon sources for the formation of citric acid (Ikeno et al. 1975; Stottmeister and Hoppe, 1991; Grewal and Kalra, 1995; Mansfeld et al. 1995; Crolla and Kennedy, 2001; Crolla and Kennedy, 2004; Venter et al. 2004) or lipid production (Papanikolaou and Aggelis, 2002). Intracellular nitrogen limitation and low intracellular nitrogen content (Briffaud and Engasser, 1979; Moresi, 1994; Anastassiadis et al. 2002; Anastassiadis et al. 2004), occurring after

*Corresponding author 


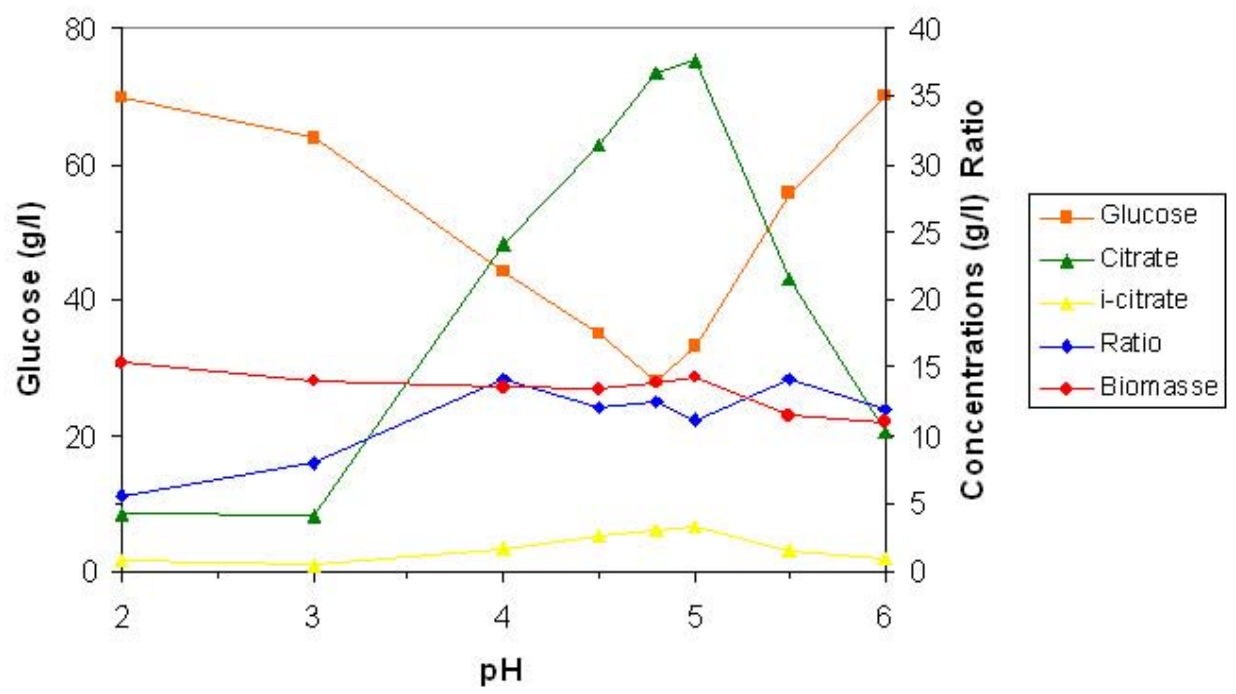

Figure 1. $\mathrm{pH}$ Influence on continuous citric acid fermentation with iron supply at a residence time of about $40 \mathrm{hrs}\left(3 \mathrm{~g} / \mathrm{NH}{ }_{4} \mathrm{Cl}\right.$, $120 \mathrm{~g} / \mathrm{l}$ glucose and $5 \mu \mathrm{M}$ iron).

extracellular nitrogen exhaustion and entering a transition phase, and the increase in intracellular $\mathrm{NH}_{4}^{+}$concentration, possibly caused by proteolysis, are the most important factors influencing and triggering out citric acid formation and secretion in yeasts (Anastassiadis et al. 1993; Anastassiadis 1994; Anastassiadis et al. 1994; Anastassiadis et al. 2001; Anastassiadis et al. 2002; Anastassiadis et al. 2004). Intracellular accumulation of $\mathrm{NH}_{4}{ }^{+}$found in cytoplasm of $A$. niger (Röhr and Kubicek, 1981; Habison et al. 1983) and in Candida oleophila (Anastassiadis et al. 2002), possibly caused by a disturbances in protein or nucleic acid turn over, uncouples citrate feed back inhibitory effect on phosphofructokinase, enabling an unlimited flow through glycolysis. A further increase of glycolysis flow is obtained by the stimulation of pyruvate kinase through fructose bi-phosphate (Habison et al. 1979; Kubicek and Röhr, 1980; Habison et al. 1983; Kubicek et al. 1984; Milson and Meers, 1985). A negative effect on pyruvate kinase isn't known, so there is no need for any kind of control at this point (Meixner-Monori et al. 1984).

Utilizing glucose as carbon source, the basic principle, extensively investigated in $A$. niger, of oxaloacetate formation by anaplerotic sequences, e.g. by the key enzyme pyruvate carboxylase for citric acid production, (Kapoor et al. 1982; Milson, 1987; Peksel et al. 2002) and phosphoenol carboxykinase (Crueger and Crueger, 1989), the flux delay and inhibition of TCA cycle ( $\alpha$-oxoglutarate dehydrogenase inhibition) and high activity of citrate synthase, is also valid for yeast strains. Glyoxylate cycle is involved in citric acid synthesis in case that acetate, other $\mathrm{C}_{2}$ sources or aliphatic compounds are used as carbon sources. A positive control of phosphofructokinase by ammonium ions, enabling supply of citrate synthase by acetyl-Co A and oxaloacetate, even a possible repression of $\alpha$-ketoglutarate dehydrogenase through high glucose and ammonium concentration (Kubicek and Röhr, 1978; Röhr et al. 1983), or inhibition of its activity by oxaloacetate (MeixnerMonori et al. 1985) doesn't explain completely intracellular accumulation and secretion of citric acid. Cis-aconitate has also been assumed to inactivate the only irreversible reaction of tricarboxylic acid cycle (Kubicek and Röhr 1986). The increasing concentration of $\alpha$-ketoglutarate caused by oxaloacetate inhibition, inhibits isocitrate dehydrogenase and thus a further $\alpha$-ketoglutarate formation. As a result, increasing citrate concentration inhibits isocitrate dehydrogenase and reaching a critical level it stops its further metabolism (Agrawal et al. 1983; MeixnerMonori et al. 1985; Grewal and Kalra, 1995), causing a complete block of TCA cycle. An additional block of citrate cycle occurs at succinate dehydrogenase level by oxaloacetate.

Significant cytological, morphological and physiological changes (e.g. cell wall composition, cell compartmentalization, pellet formation, vacuolization and formation of storage compounds and polyols) take place in both microbial systems and clear variations are occurring in terms of electron transport and energy coupling (Kisser et al. 1980; Honecker et al. 1989; Papagianni et al. 1999; Paul et al. 1999; Pera and Callieri, 1999; Anastassiadis et al. 2002; Haq et al. 2002). Alternative respiration chains with a higher oxygen demand, functioning without yielding of ATP has also been reported to be involved in citrate accumulation (Kubicek et al. 1980; Zehentgruber et al. 1980; Röhr et al. 1983; Wallrath et al. 1991), leading to higher glucolysis rate and substrate phosphorylation (Wallrath et al. 1991). Byproducts (e.g. polyols) are produced in late fermentation phases that can be reconsumed forming citric acid.

The overall success of citric acid production depends to a large extent on the regulation of the TCA cycle. However, 


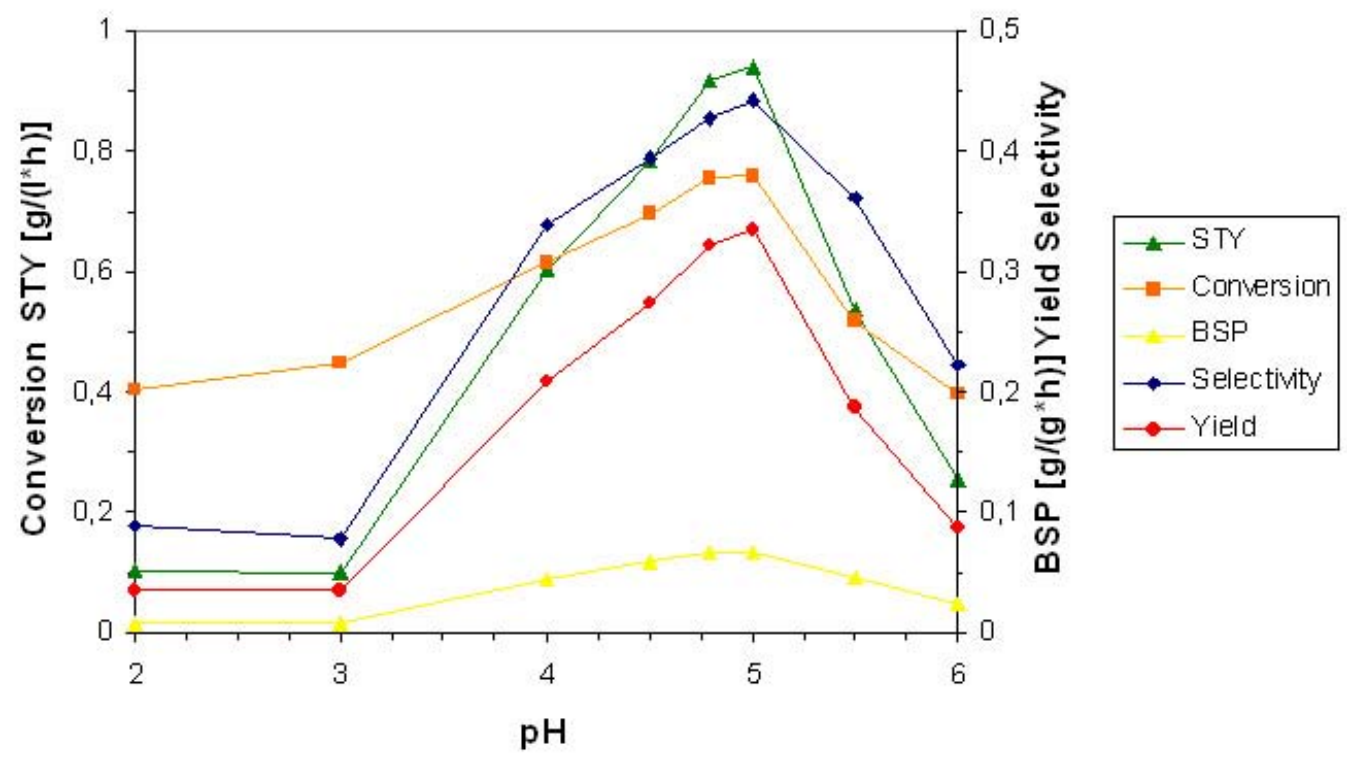

Figure 2. pH Influence on space-time yield, biomass specific productivity and continuous citric acid fermentation with iron supply at a residence time of about $40 \mathrm{hrs}\left(3 \mathrm{~g} / \mathrm{l} \mathrm{NH} \mathrm{Nl}_{4}, 120 \mathrm{~g} / \mathrm{l}\right.$ glucose and $5 \mu \mathrm{M}$ iron).

the excretion mechanism in $A$. niger remained unclear (Grewal and Kalra, 1995).A little information is found in literature regarding the mechanism of citric acid secretion in yeasts and fungi. Whereas transportation of citrate from mitochondria into cytoplasm by citrate malate translocase is well known, excretion mechanism of citrate from cytoplasm into the medium still remained unknown. Marchal et al.(1980) found almost equal concentrations of citrate and isocitrate in the cells of $C$. lipolytica and in fermentation medium, suggesting a passive diffusion of citrate and isocitrate over cell membrane. McKayet al.(cited in Gutierrez and Maddox, 1993) assumed a passive diffusion of citrate and isocitrate over the cell membrane, in which the extracellular ratio between citrate and isocitrate corresponds to the intracellular ratio. Intracellular accumulation of citric acid and citrate secretion are obviously two different phenomena. A specific active transport system for citric acid secretion preferring citrate over isocitrate was found for the first time in Candida oleophila, based on simultaneous extra- and intracellular measurements of citrates and glucose acting as speed determining factor, well explaining overproduction of citric acid against a very high concentration gradient between the cell and fermentation medium (Anastassiadis et al. 1993; Anastassiadis, 1994; Anastassiadis et al. 1994; Anastassiadis et al. 2001; Anastassiadis et al. 2002). Netik et al. (1997) reported later about a $\Delta \mathrm{pH}$-driven $\mathrm{H}^{+}$-symport dependent system for citric acid export in manganesedeficient cells of $A$. niger, also claiming that only a passive diffusion through plasma membrane had been before reported for citrate excretion in yeasts.

The central aspect of present work was to investigate the influence of $\mathrm{pH}$ on continuous citric acid secretion by a specific active transport system, as well as on the elemental biomass composition in free growing chemostat cultures of Candida oleophila ATCC 20177. A mechanism for citric acid secretion by a specific $\mathrm{pH}$ dependent active transport system is presented.

\section{MATERIALS AND METHODS}

\section{Microbial system}

Candida oleophila ATCC 20177 var. (obtained from Dr. Siebert, Jungbunzlauer Co. and later $\mathrm{H}$ and $\mathrm{R}$, Bayer, Germany) was used through all experiments in this present work that was selected under many yeast strains during an extensive screening (Anastassiadis et al. 1993; Anastassiadis, 1994; Anastassiadis et al. 1994; Anastassiadis et al. 2001; Anastassiadis et al. 2002). Yeast malt extract agar plates (YME) inoculated with $C$. oleophila were incubated for 2-3 days and stored at $4^{\circ} \mathrm{C}$. Cultures were refreshed every 2-3 months. Glycerine cultures $\left(30 \%\right.$ glycerine) were frozen at -20 or $-80^{\circ} \mathrm{C}$ as well.

\section{Chemostat experiments}

The influence of $\mathrm{pH}$ on continuous citric acid fermentation and secretion was investigated in chemostat experiments carried out in 1 litter magnetically stirred double glass fermenter (Research Centre Jülich, RCJ, Germany) with a working volume of about $460 \mathrm{ml}$ at $30^{\circ} \mathrm{C}, 1300 \mathrm{rpm}$ and a constant aeration rate of $0.145 \mathrm{vvm}$. Pure oxygen was used in order to satisfy the low oxygen transfer in small glass fermenter. At the beginning of experiments, the microorganism was simply transferred from a fresh agar plate into fermenter via a shake flask supplied with silicon tubing and quick connectors using a peristaltic pump. 
Temperature was controlled using a circulation water bath (Lauda KG, Königshofen, Germany). $\mathrm{pH}$ was automatically controlled by the addition of $22.5 \% \mathrm{NaOH}$ solution $(\mathrm{w} / \mathrm{v})$ using a pH controller (Ingold Meßtechnik $\mathrm{GmbH}$, Steinbach) and a peristaltic pump. An automatic gravimetric dosing system (Sartorius, Göttigen, Germany) and a peristaltic pump (Watson-Marlow Ltd.) were used for constant medium feeding into fermenter. The residence time $(\mathrm{hr})$ that corresponds to 1 /dilution rate (1/D) was calculated under steady state conditions based on the working volume of fermenter via medium feed flux and $\mathrm{NaOH}$ flux. Residence time is the time required to replace once the working volume of fermenter. Achieving of steady state conditions was detected by monitoring the concentration of products, substrate and biomass and optical density (OD) on a daily basis. During entire fermentation and until achieving state conditions, samples were frequently taken out and analysed on a daily basis. Continuous fermentation was still carried out for a while under unchanged conditions, also after achieving steady state conditions. Fermentation times of several days or weeks were often required for achieving steady state conditions. During entire duration of fermentation, medium feeding rate, $\mathrm{NaOH}$ consumption and physical parameters (e.g. $\mathrm{pH}$ of fermentation broth was periodically measured externally and corrected) were measured and evaluated. Fermentation data presented here didn't result from just only one single measurement, however they were obtained based on long time measurements during continuous fermentation, meaning several days or weeks, until reaching steady state conditions. They represent an average of several measurements attained after achieving steady state conditions during a period of several days. Chemostat cultures carried out under controlled constant conditions are tending to reach steady state conditions, in which all fermentation parameters are remaining constant (unchanged) as time passes. In generally, between five and 10 generations (residence times, RT) are necessary for getting steady state conditions, depending on process and strain stability.

\section{Feed medium (basic medium, BM)}

A basic fermentation medium of following composition was used in a series of experiments for the preliminary orientation's investigation of $\mathrm{pH}$ influence on iron uptake and citrate formation (BM): $3 \mathrm{~g} / 1 \mathrm{NH}_{4} \mathrm{Cl}, 120 \mathrm{~g} / \mathrm{l}$ glucose, $0.7 \mathrm{~g} / 1 \mathrm{KH}_{2} \mathrm{PO}_{4}, 0.35 \mathrm{~g} / 1 \mathrm{MgSO}_{4} \times 7_{2} \mathrm{O}, 0.11 \mathrm{~g} / 1(0.5 \mathrm{mM})$ $\mathrm{MnSO}_{4} \times 4 \mathrm{H}_{2} \mathrm{O}, 5 \mu \mathrm{M} \mathrm{FeSO}_{4} \times 7 \mathrm{H}_{2} \mathrm{O}, 0.001 \mathrm{~g} / \mathrm{l} \mathrm{CuSO} \mathrm{C}_{4} \mathrm{x}$ $5 \mathrm{H}_{2} \mathrm{O}, 0.021 \mathrm{~g} / \mathrm{l} \mathrm{ZnSO} \mathrm{Z}_{4} \times 7 \mathrm{H}_{2} \mathrm{O}, 0.004 \mathrm{~g} / \mathrm{CoSO}_{4} \times 7 \mathrm{H}_{2} \mathrm{O}$, $0.04 \mathrm{~g} / 1 \mathrm{H}_{3} \mathrm{BO}_{3}, 0.1 \mathrm{~g} / 1 \mathrm{CaCl}_{2}, 0.1 \mathrm{~g} / \mathrm{l} \mathrm{NaCl}, 0.1 \mathrm{mg} / \mathrm{l}$ potassium iodide $(\mathrm{KJ}), 2.5 \mathrm{~g} / \mathrm{l}$ citric acid, $0.2 \mathrm{mg} / 1$ $\mathrm{Na}_{2} \mathrm{MoO}_{4} \times 2 \mathrm{H}_{2} \mathrm{O}, 2 \mathrm{mg} / \mathrm{l}$ Thiamine- $\mathrm{HCl}, 0.25 \mathrm{mg} / \mathrm{l}$ Biotin, $0.625 \mathrm{mg} / \mathrm{l}$ Pyridoxine-HCl, $0.625 \mathrm{mg} / \mathrm{l} \mathrm{Ca-D-Pantothenate,}$ $0.5 \mathrm{mg} / \mathrm{l}$ Nicotinic acid.

\section{Non producing medium (BM with $6 \mathrm{~g} / \mathrm{l} \mathrm{NH}_{4} \mathrm{Cl}$ and $120 \mathrm{~g} /$ glucose)}

The basic medium, however with $6 \mathrm{~g} / \mathrm{NH}_{4} \mathrm{Cl}, 120 \mathrm{~g} / \mathrm{l}$ glucose and $0.5 \mathrm{mM}$ iron, was used for the investigation of $\mathrm{pH}$ influence on biomass formation under non producing conditions.

\section{Production medium}

In a second series of experiments, a production medium with $4.5 \mathrm{~g} / 1 \mathrm{NH}_{4} \mathrm{Cl}$, analogously increased concentrations of residual compounds (at factor 1.5 higher than in medium with $3 \mathrm{~g} / \mathrm{l} \mathrm{NH} \mathrm{H}_{4}$ ), however with $1.125 \mathrm{mM}$ manganese and without iron supply, and with $250 \mathrm{~g} / 1$ glucose was used for the investigation of $\mathrm{pH}$ influence on citric acid secretion.

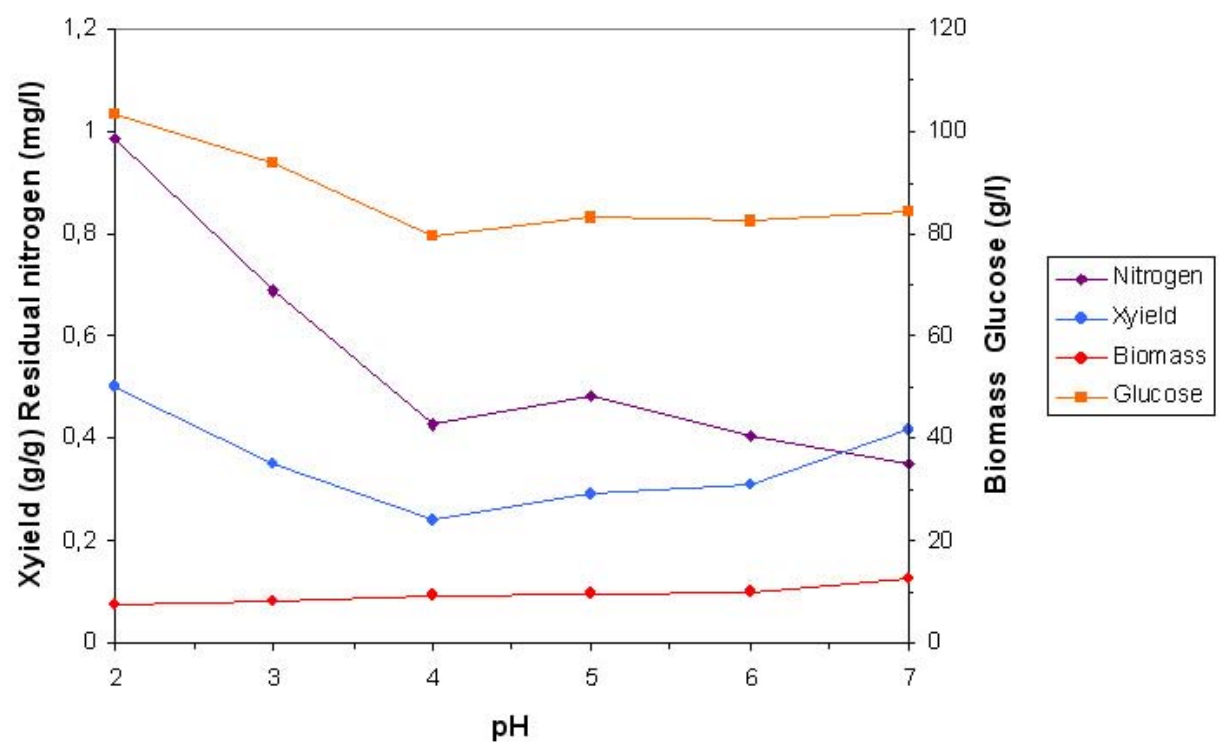

Figure 3. $\mathrm{pH}$ Influence on continuous biomass formation and biomass yield $\left(\mathrm{X}_{\text {yield }}\right)$ under non producing conditions $\left(6 \mathrm{~g} / \mathrm{l} \mathrm{NH}_{4} \mathrm{Cl}\right.$, $120 \mathrm{~g} / \mathrm{l}$ glucose and $5 \mu \mathrm{M}$ iron). 


\section{Medium composition}

$4.5 \mathrm{~g} / 1 \mathrm{NH}_{4} \mathrm{Cl}, 250 \mathrm{~g} / 1$ glucose, $1.05 \mathrm{~g} / 1 \mathrm{KH}_{2} \mathrm{PO}_{4}, 0.525 \mathrm{~g} / 1$ $\mathrm{MgSO}_{4}$ × $7 \mathrm{H}_{2} \mathrm{O}, 0.2475 \mathrm{~g} / \mathrm{l}(1.125 \mathrm{mM}) \mathrm{MnSO}_{4} \times 4 \mathrm{H}_{2} \mathrm{O}, 0$ $\mu \mathrm{M} \mathrm{FeSO}{ }_{4} \times 7 \mathrm{H}_{2} \mathrm{O}, 0.0015 \mathrm{~g} / \mathrm{CuSO}_{4} \times 5 \mathrm{H}_{2} \mathrm{O}, 0.0315 \mathrm{~g} / 1$ $\mathrm{ZnSO}_{4} \times 7 \mathrm{H}_{2} \mathrm{O}, 0.006 \mathrm{~g} / \mathrm{CoSO}_{4} \times 7 \mathrm{H}_{2} \mathrm{O}, 0.06 \mathrm{~g} / 1 \mathrm{H}_{3} \mathrm{BO}_{3}$, $0.15 \mathrm{~g} / \mathrm{l} \mathrm{CaCl}, 0.15 \mathrm{~g} / \mathrm{l} \mathrm{NaCl}, 0.15 \mathrm{mg} / \mathrm{l}$ potassium iodide (KJ), $2.5 \mathrm{~g} / \mathrm{l}$ citric acid, $0.3 \mathrm{mg} / \mathrm{N} \mathrm{Na}_{2} \mathrm{MoO}_{4} \times 2 \mathrm{H}_{2} \mathrm{O}, 2 \mathrm{mg} / \mathrm{l}$ Thiamine- $\mathrm{HCl}, 0.375 \mathrm{mg} / \mathrm{l}$ Biotin, $0.9375 \mathrm{mg} / \mathrm{l}$ Pyridoxine$\mathrm{HCl}, 0.9375 \mathrm{mg} / \mathrm{l} \mathrm{Ca}-\mathrm{D}-$ Pantothenate, $0.75 \mathrm{mg} / \mathrm{l}$ Nicotinic acid.

Silicon oil or polypropylene glycol was used as antifoaming agent. The 20 litter medium was sterilized in autoclave for 30-60 min at $121^{\circ} \mathrm{C}$. Vitamins and $\mathrm{NH}_{4} \mathrm{Cl}$ were added separately into media following filtration through a $0.2 \mu \mathrm{m}$ membrane filter (Sartorius, Göttingen, Germany). The glucose concentration and specific weight $(\mathrm{g} / \mathrm{ml})$ of each new medium and the specific weight of each new $\mathrm{NaOH}$ solution were determined and considered in all of following evaluations (e.g. determination of RT, real glucose concentration of feeding medium, specific parameters).

\section{Optical density (OD)}

Optical density (OD) was measured at $660 \mathrm{~nm}$ using a spectrophotometer (CPS-240, Shimadzu, Japan) and it was used for daily monitoring of achieving steady state conditions in fermenter.

\section{Dry biomass}

Dry biomass was measured using the filter method. $10 \mathrm{ml}$ of fermentation broth were quickly filtered through a $5 \mathrm{~cm}$ diameter filter with $0.2 \mu \mathrm{m}$ pores. The biomass was washed 3 to 4 times with $0.9 \% \mathrm{NaCl}$ solution and distilled water and dried for $10 \mathrm{~min}$ in a microwave oven at a low power between 200 and 400 watt in order to prevent burning of biomass. After stabilizing of weight in a desiccator for 15 min, dry biomass was determined by the difference of weight before and after filtration and drying of filter.

\section{Qualitative and quantitative analysis}

Organic acids, glucose, ammonia nitrogen and intracellular concentrations were analysed as described in Anastassiadis, 1993; Anastassiadis et al. 1993; Anastassiadis, 1994; Anastassiadis et al. 2001 and Anastassiadis et al. 2002. A new HPLC application was developed for the analysis of carbonic acids that can separate the chemically related citric and isocitric acid (Anastassiadis, 1993; Anastassiadis et al. 1993). A solvent with $5 \mathrm{mM}$ TBA (tetrabutyle ammonium hydrogen sulphate) and $2 \%$ acetonitrile was used as mobile phase at a flow rate of $1 \mathrm{ml} / \mathrm{min}$. The column temperature was kept at $37^{\circ} \mathrm{C}$. An $5 \mathrm{C}_{18} \mathrm{AB}$ column (Macherey and Nagel, Düren, Germany) was used as stationary phase. A pressure of 0.4-0.5 bar was applied in the eluent bottle using helium gas. The substances were detected by a UV detector at $210 \mathrm{~nm}$ and the concentrations were evaluated by a computer program (AXXIOM). The same method was also used by Antonucci et al. (2001) for the separation and analysis of citric and isocitric acid (no reference to above method). For glucose analysis, an HPLC application was developed that also enables separation glucose from gluconic acid. A Nucleosil $\mathrm{NH}_{2}$ column and a mobile phase with $75 \%$ acetonitrile were used at $40-45^{\circ} \mathrm{C}$ and $1-1.5$ $\mathrm{mL} / \mathrm{min}$ flow rate (Anastassiadis et al. 1993; Anastassiadis, 1994; Anastassiadis et al. 1994; Anastassiadis et al. 2001; Anastassiadis et al. 2002). The eluent was able to use for longer time, because of the eluent's high toxicity (no microbial growth occurred in the eluent at $75 \%$ acetonitrile). Glucose was detected using an RI detector (S4110/S 1000, Sykam).

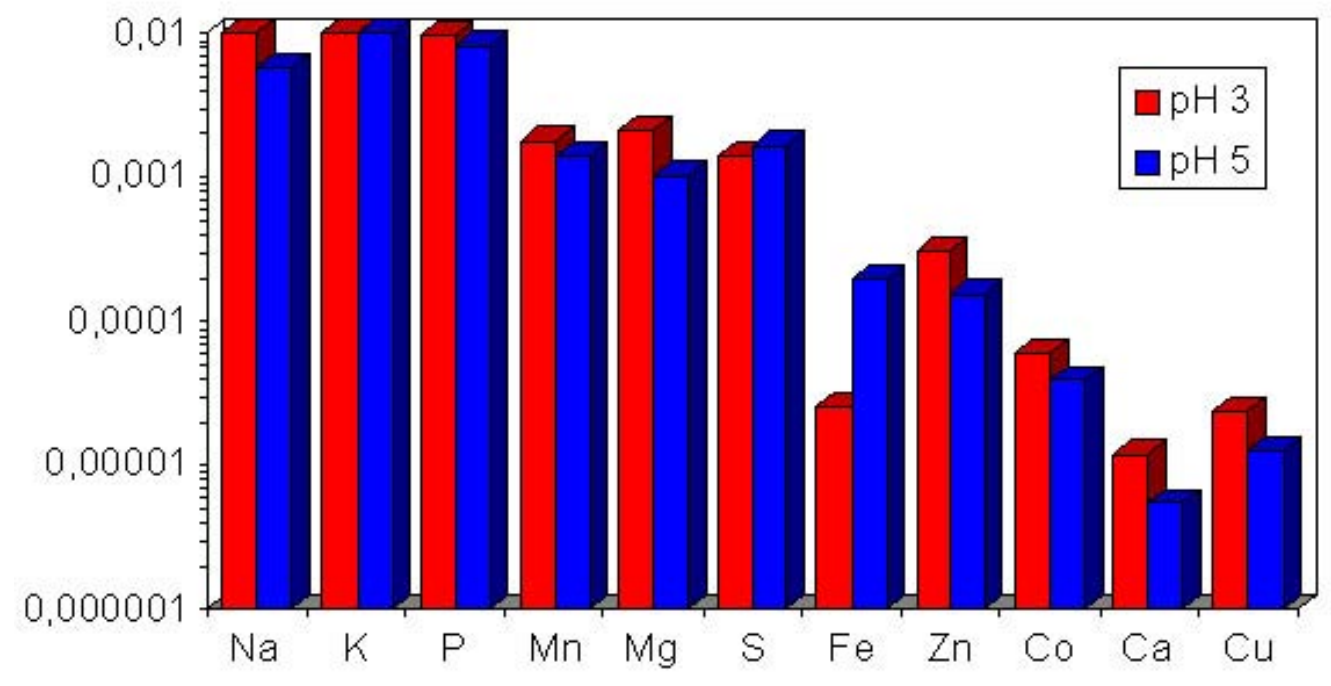

Figure 4. Logarithmic presentation of elemental composition of biomass of Candida oleophila at pH 3 and 5 (Chemostat, basic medium with $3 \mathrm{~g} / \mathrm{l} \mathrm{NH}{ }_{4} \mathrm{Cl}, 120 \mathrm{~g} / \mathrm{l}$ glucose and $5 \mu \mathrm{M} \mathrm{Fe}$ ). 
Intracellular measurements of citric and isocitric acid and glucose

Intracellular concentrations of citric, isocitric acid and glucose were precisely evaluated using the above HPLC methods after their extraction following next procedure.

1. $10 \mathrm{ml}$ of fresh fermentation broth of known biomass concentration (tubes were hold in ice) were immediately filtered using a vacuum pump and washed 3-4 times using a cold $0.9 \% \mathrm{NaOH}$ solution.

2. Intracellular acids and glucose were extracted by placing the filter with biomass in boiling ethanol for $5 \mathrm{~min}$. Thereafter, filter and solids were dried using a vacuum rotator and resolved in $5 \mathrm{ml}$ distilled water.

3. The sample was filtered using a filter with $0.2 \mu \mathrm{m}$ pores and analysed. No destruction of metabolites was found in the controls submitted to the same treatment method.

4. Intracellular concentrations of various metabolites were determined and presented in $\mathrm{g}$ per gram dried biomass or in $\mathrm{mM}$ (under the consideration that cell volume corresponds to an average value of about $2.2 \mu \mathrm{l} / \mathrm{mg}$ dry weight that was determined) based on the report of Marchal et al. (1980) for cell volume of Saccharomycopsis lipolytica. The authors give an average value of $0.43 \mathrm{ml} \mathrm{x}$ (g wet weight $)^{-1}$. The above value of $2.2 \mu \mathrm{l} /(\mathrm{mg}$ dry weight) was calculated according to the ratio between wet and dried weight of about 5 determined for cells of $C$. oleophila (used in present work).

Similar values were determined for cell volume of $C$. oleophila as well, using a method involving a radioactive polymer, which can not diffuse into the internal volume of yeast cells (D. Brücher, RCJ). In generally, cell volume of microorganisms arranges between 2 and $4 \mu \mathrm{l} /(\mathrm{mg}$ dry weight) (Knowles, 1977). Höfer et al. 1985 determined a value of $2 \mu \mathrm{l} /(\mathrm{mg}$ dry weight) for the cell volume of Rhodotorula gracilis (glutinis).

\section{ATP and ADP analysis}

ATP and ADP ratio was determined at the Institute of Biotechnology 1 of Research Centre Jülich (Jülich, Germany) using the luciferin/luciferase method for ATP measurement. After measurement of ATP, ADP was first transformed into ATP using PEP and pyruvate kinase and measured as ATP (Lundin et al. 1976, modified; Schimz et al. 1981).

\section{Ammonium nitrogen analysis}

Ammonium nitrogen was analysed as has been described in Anastassiadis et al. (2002).

\section{RESULTS}

The influence of $\mathrm{pH}$ on the growth and elemental biomass composition of $C$. oleophila and citric acid secretion was investigated in different series of chemostat experiments.

\section{pH influence on continuous citric acid formation ( $3 \mathrm{~g} / \mathrm{l} \mathrm{NH}{ }_{4} \mathrm{Cl}$ and $120 \mathrm{~g} / \mathrm{l}$ glucose)}

The influence of $\mathrm{pH}$ on growth of $C$. oleophila and continuous citric acid formation was investigated in a series of preliminary orientation's experiments, carried out in chemostat cultures at a residence time of about $40 \mathrm{hrs}(\mathrm{D}=$ $0.025 \mathrm{~h}^{-1}$ ) using the basic fermentation medium (BM) with $3 \mathrm{~g} / 1 \mathrm{NH}_{4} \mathrm{Cl}$ and $120 \mathrm{~g} / \mathrm{l}$ glucose. Figure 1 illustrates the course of biomass, glucose, citrate and isocitrate concentration as well as the ratio between citrate and isocitrate as a function of $\mathrm{pH}$. Citric acid was continuously produced at a pH range between 2 and 6 . Only $4.22 \mathrm{~g} / 1$ of citric acid were measured at $\mathrm{pH} 2$ and $4.02 \mathrm{~g} / 1$ at $\mathrm{pH} 3$. Increasing the $\mathrm{pH}$ from 3 to 4 , citric acid concentration increased continuously by a factor of about 6 reaching a steady state concentration of $24.1 \mathrm{~g} / 1$ after several days. Isocitric acid reached in generally a stationary steady state concentration within shorter times compared with citrate. Highest citrate concentration of $37.6 \mathrm{~g} / \mathrm{l}$ was achieved at $\mathrm{pH}$ 5 , compared with $24.1 \mathrm{~g} / \mathrm{l}$ and only $10.2 \mathrm{~g} / 1$ reached at $\mathrm{pH} 4$ and $\mathrm{pH}$ 6, respectively. Isocitric acid reached concentrations between 0.5 and $3.36 \mathrm{~g} / \mathrm{l}$. A ratio between citrate and isocitrate of around 12 was determined at most of $\mathrm{pH}$ values. Residual glucose concentrations between 27 $\mathrm{g} / \mathrm{l}(\mathrm{pH} \mathrm{5)}$ and $70.2 \mathrm{~g} / \mathrm{l}(\mathrm{pH} \mathrm{6)}$ or $69.7 \mathrm{~g} / \mathrm{l}(\mathrm{pH} \mathrm{2)}$ were measured under steady state conditions, corresponding to conversions (conversion means the consumed glucose/feeding medium glucose, scale $0-1$, which corresponds to $0-100 \% ; 100 \%$ conversion corresponds to total conversion of glucose) between $40 \%$ and about $76 \%$ (Figure 2). The decreasing of $\mathrm{pH}$, resulted to continuous increase of biomass concentration, starting with about 11 $\mathrm{g} / \mathrm{l}$ biomass at $\mathrm{pH} 6$ and reaching $15.3 \mathrm{~g} / \mathrm{l}$ at $\mathrm{pH} 2$ (factor 1.4) (Figure 1). A correlation factor between $0.27(\mathrm{pH} 5.5)$ and $0.34(\mathrm{pH} 2)$ has been determined between biomass and OD (Biomass/OD).

As Figure 2 shows, product concentration, space-time yield (STY, volumetric productivity that means g product/[litter $\mathrm{x}$ $\mathrm{hr}]$ ), biomass specific productivity (BSP, it means $\mathrm{g}$ product/[g dry biomass $\mathrm{x} h \mathrm{hr}]$ ) and additional specific parameters were very poor at lower $\mathrm{pH}$ values (e.g. $\mathrm{pH} 2$ and 3) in opposite of higher biomass concentrations. Highest STY of $0.94 \mathrm{~g} /(1 \mathrm{x} \mathrm{hr})$ was achieved at $\mathrm{pH} 5$ and BSP of $0.067 \mathrm{~g} /(\mathrm{g} \mathrm{x} \mathrm{hr})$ at $\mathrm{pH} 4.8$ compared with $0.11 \mathrm{~g} /(1 \mathrm{x}$ $\mathrm{hr})$ and $0.0069 \mathrm{~g} /(\mathrm{g} \mathrm{x} \mathrm{hr})$ found at $\mathrm{pH} 3$. Highest selectivity (selectivity means $\mathrm{g}$ of product/g of converted glucose; scale $0-1$ or in $\%$ ) of $44.3 \%$, yield (yield means $g$ of product/g of feeding glucose; scale $0-1$ or in $\%$ ) of $33.6 \%$ and conversion of $75.9 \%$ were determined at $\mathrm{pH} 5$ as well. About $7.7 \%$ selectivity, $3.5 \%$ yield and $45 \%$ conversion were determined at $\mathrm{pH} 3$ instead (Figure 2). Similar results were observed in further experiments with $3 \mathrm{~g} / \mathrm{l} \mathrm{NH}_{4} \mathrm{Cl}, 120$ $\mathrm{g} / \mathrm{l}$ glucose and without any iron supply (data not shown 


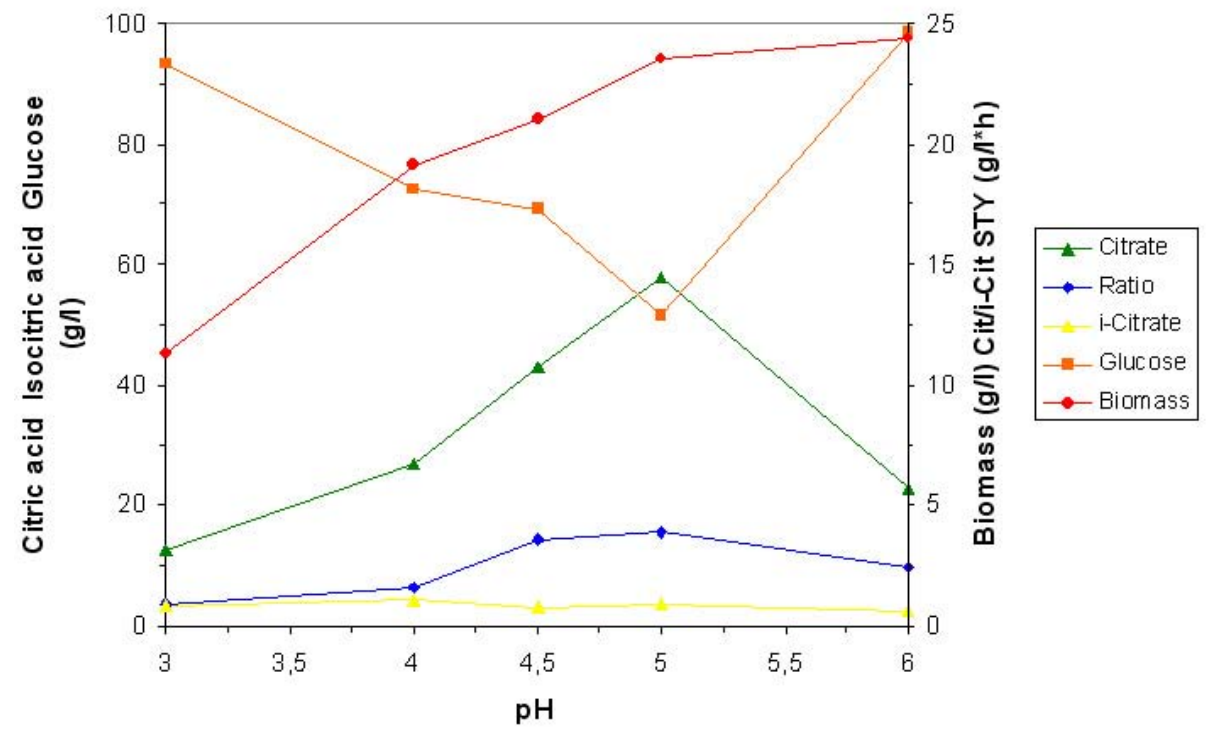

Figure 5. Influence of $\mathrm{pH}$ on continuous citric acid fermentation under optimised conditions $\left(4.5 \mathrm{~g} / \mathrm{NH} \mathrm{N}_{4} \mathrm{Cl}, 250 \mathrm{~g} / \mathrm{g}\right.$ glucose and a residence time of $60 \mathrm{hrs}$.

here), indicating that traces of iron are present in other media components.

\section{$\mathrm{pH}$ influence on continuous biomass formation under non producing conditions $\left(6 \mathrm{~g} / \mathrm{l} \mathrm{NH}_{4} \mathrm{Cl}\right.$ and $120 \mathrm{~g} / \mathrm{l}$ glucose)}

A series of chemostat experiments was carried out at $\mathrm{pH}$ between 2 and 7 for the investigation of $\mathrm{pH}$ influence on continuous growth of $C$. oleophila, independent from citric acid production. The basic medium as has been described in the material and methods was used, which contained an excessive $\mathrm{NH}_{4} \mathrm{Cl}$ concentration of $6 \mathrm{~g} / \mathrm{l}$ and $0.5 \mathrm{mM}$ iron. Residual nitrogen was measured in all of the experiments, which decreased from $0.99 \mathrm{~g} / \mathrm{l}(\mathrm{pH} 2)$ to $0.35 \mathrm{~g} / \mathrm{l}(\mathrm{pH} 7)$. No citric acid was formed by $C$. oleophila in the presence of nitrogen in agreement of previous reports (Anastassiadis et al. 2002; Anastassiadis et al. 2004). The residual glucose reached values between $79.7 \mathrm{~g} / 1(\mathrm{pH} 4)$ and $103.3 \mathrm{~g} / 1(\mathrm{pH}$ 2 ), corresponding to glucose conversions ( $\mathrm{g}$ of consumed glucose/g glucose of feeding medium) between $32.6 \%$ and $12.7 \%$, respectively. Biomass concentration dropped continuously at raising $\mathrm{pH}$ between 2 and 6 , from $7.4 \mathrm{~g} / 1$ to $12.3 \mathrm{~g} / 1$ (factor 1.67). Biomass yields (g biomass $/ \mathrm{g}$ of consumed glucose) between $0.24(\mathrm{pH} \mathrm{4})$ and $0.5(\mathrm{pH} 2)$ were determined dependent on $\mathrm{pH}$ in fermenter (Figure 3).

\section{Elemental biomass composition of $C$. oleophila at pH 3 and 5 (basic medium with $3 \mathrm{~g} / \mathrm{l} \mathrm{NH} \mathrm{N}_{4} \mathrm{Cl}$ and 120 g/l glucose)}

The elemental biomass composition in biomass of $C$. oleophila, obtained from chemostat cultures grown at $\mathrm{pH} 3$ and $\mathrm{pH} 5$, was analysed by the Analytical Chemistry Department of RCJ (Jülich, Germany). Figure 4 shows the elemental composition at $\mathrm{pH} 3$ and 5, which is presented as the logarithm of element concentration. No significant differences were found in the content of macroelements ( $\mathrm{P}$, $\mathrm{S})$ between $\mathrm{pH} 3$ and $\mathrm{pH}$ 5. However, a higher content of the trace elements zinc, cobalt, calcium and copper (excess factors, needed at higher concentrations than the biomass contains for optimum production) was found in biomass of C. oleophila at $\mathrm{pH} 3$. Slightly higher are the concentrations of sodium, magnesium and manganese at $\mathrm{pH} 3$. The iron content of $200 \mathrm{ppm}$ found in biomass of C. oleophila at $\mathrm{pH}$ 5 was at about factor 8 higher than at $\mathrm{pH} 3$ (26 ppm), indicating a facilitating iron uptake in Candida oleophila at higher $\mathrm{pH}$.

pH influence on continuous citric acid secretion by the specific active transport system $(4.5 \mathrm{~g} / \mathrm{l}$ $\mathrm{NH}_{4} \mathrm{Cl}$ and $250 \mathrm{~g} / \mathrm{l}$ glucose)

In a new series of chemostat experiments, the $\mathrm{pH}$ influence on intracellular concentrations of citrates and glucose and on citric acid secretion was investigated at a residence time of about $60 \mathrm{hrs}$ (corresponds to a dilution rate of about $\mathrm{D}=\sim 0.017 \mathrm{~h}^{-1}$ ), using an optimised production medium with $4.5 \mathrm{~g} / 1 \mathrm{NH}_{4} \mathrm{Cl}, 250 \mathrm{~g} / 1$ glucose, $1.125 \mathrm{mM}$ of manganese and without iron supply (traces of iron are present in other chemical compounds). The addition of iron has been found to enhance biomass formation and to affect continuous citric acid production significantly. As Figure 5 shows, a maximum citric acid concentration of $57.8 \mathrm{~g} / 1$ was achieved at $\mathrm{pH} 5$, compared with 43.1 and only $22.8 \mathrm{~g} / 1$ reached at $\mathrm{pH} 4.5$ (factor 1.34 or $74.6 \%$ ) and $\mathrm{pH} 6$ (factor 2.54 or $39.5 \%$ ), respectively. Only $12.4 \mathrm{~g} / 1$ were obtained at $\mathrm{pH} 3$ (factor 4.7 or $21.5 \%$ ). The highest ratio between citrate and isocitrate of 15.6 was also found at $\mathrm{pH} \mathrm{5,} \mathrm{compared} \mathrm{with}$ only 3.7 or 9.9 identified at $\mathrm{pH} 3$ and 6 , respectively. Highest isocitric acid concentration of $4.2 \mathrm{~g} / \mathrm{l}$ was measured at $\mathrm{pH} 4$ instead. Biomass concentration increased steadily 
with raising $\mathrm{pH}$ and achieved $23.54 \mathrm{~g} / \mathrm{l}$ at $\mathrm{pH} 5$ and 24.42 $\mathrm{g} / \mathrm{l}$ at $\mathrm{pH} 6$, corresponding to a factor of 2.16 between $\mathrm{pH} 6$ and $\mathrm{pH} 3(11.3 \mathrm{~g} / \mathrm{l})$.

Figure 6 shows space-time yield (STY), biomass-specific productivity (BSP), the ratio between ATP and ADP and the specific parameters product selectivity, conversion and product yield as a function of $\mathrm{pH}$. Highest STY of $0.96 \mathrm{~g} /(1$ $\mathrm{x} \mathrm{hr}$ ) was obtained at optimum $\mathrm{pH} 5$, compared with only $0.21 \mathrm{~g} /(1 \mathrm{x} \mathrm{hr})$ or $0.38 \mathrm{~g} /(1 \times \mathrm{hr})$ reached at $\mathrm{pH} 3(21.5 \%)$ and $\mathrm{pH} 6(39.5 \%)$. Highest BSP of $0.041 \mathrm{~g} /(\mathrm{g} \mathrm{x} \mathrm{hr})$ was also found at $\mathrm{pH} 5$, in comparison to only $0.018 \mathrm{~g} /(\mathrm{g} \mathrm{x} \mathrm{hr})$, $0.0156 \mathrm{~g} /(\mathrm{g} \mathrm{x} \mathrm{hr})$ or $0.034 \mathrm{~g} /(\mathrm{g} \mathrm{x} \mathrm{hr})$, achieved at $\mathrm{pH} 3$ (44.7\%), pH $6(38 \%)$ and $\mathrm{pH} 4.5(83.3 \%)$, respectively. Highest product selectivity of $35 \%$, conversion of $76 \%$, yield (yield $=$ selectivity $\mathrm{x}$ conversion) of $26.6 \%$ and ratio between ATP and ADP of 2.65 were determined at optimum $\mathrm{pH} 5$ as well. In comparison, a selectivity of only $10 \%$, conversion of $57 \%$, yield of $5.7 \%$ and an ATP/ADP ratio of 1.31 were determined at $\mathrm{pH} 3$ (Figure 6). The ratio between ATP and ADP correlated very strongly with the extracellular citrate concentration and the ratio between citrate and isocitrate, displaying a maximum at optimum $\mathrm{pH} 5$, whereas isocitric acid showed a flat course, indicating a very strong connection between overproduction of citrate and energy state of yeast cells. Optimisation attempts running in chemostat experiments are favourably carried out at conversions lower than $80 \%$, because the complete conversion wouldn't enable the identification of complex and interacting effects occurring during an optimisation approach.

The existence of an active transport system for citric acid secretion in C. oleophila became obvious, based on citric acid transport over the cell membrane against a very high concentration gradient between intra- and extracellular citrate concentration. The active transport system was influenced by various parameters such as air saturation, temperature, medium composition and growth state of chemostat cells (residence time, growth or dilution rate). It showed a very high specificity for citrate over isocitrate (specificity factor of 33). Furthermore, the highest intracellular concentrations of citrate, isocitrate and glucose and simultaneously the lowest extracellular citric acid concentrations were determined under none or low producing conditions. In contrary, maximum extracellular citric acid concentrations were reached under conditions, where the lowest intracellular concentrations of citrate and isocitrate appeared. Intracellular isocitric acid concentration exceeded citric acid concentration significantly. Under producing conditions, isocitrate was drawn out from aconitase equilibrium towards citrate, resulting to a higher glycolysis rate and to lowering of intracellular concentration of glucose and isocitric acid (Anastassiadis et al. 1993; Anastassiadis, 1994; Anastassiadis et al. 1994; Anastassiadis et al. 2001). Based on intracellular measurements of glucose, citrate, isocitrate as well as of ATP and ADP (ATP/ADP ratio) has been investigated, whether there would be a $\mathrm{pH}$ dependency for citric acid secretion by active transport system.

As Figure 7 shows, the highest intracellular glucose concentration of $372 \mathrm{mg} / \mathrm{g}$ dried biomass, citrate concentration of $57.6 \mathrm{mg} / \mathrm{g}(\sim 136,3 \mathrm{mM}$, under the consideration that the cell volume of $C$. oleophila corresponds to $2.2 \mu \mathrm{l} / \mathrm{mg}$ dry weight, calculated from the cell volume for wet weight; Marchal et al. 1980, under the condition that $1 \mathrm{~g}$ dried biomass of $C$. oleophila corresponds to about $5 \mathrm{~g}$ wet weight) and isocitrate concentration of $156.4 \mathrm{mg} / \mathrm{g}(370.1 \mathrm{mM})$ were measured at non producing $\mathrm{pH} 3$. However, the lowest intracellular citrate concentration of only $18.6 \mathrm{mg} / \mathrm{g}$ dried biomass $(\sim 44.1 \mathrm{mM})$ and total acid concentration (citrate + isocitrate) of $51.3 \mathrm{mg} / \mathrm{g}$ dried biomass $(\sim 121.4 \mathrm{mM})$ were found at optimum $\mathrm{pH} 5$. The lowest intracellular isocitrate concentration of $30.2 \mathrm{mg} / \mathrm{g}$ dried biomass $(32.7 \mathrm{mg} / \mathrm{g}$ biomass at $\mathrm{pH} 5$ ) and glucose concentration of $43 \mathrm{mg} / \mathrm{g}$ biomass $(52 \mathrm{mg} / \mathrm{g}$ biomass at $\mathrm{pH} 5)$ were determined at $\mathrm{pH}$ 4.5 instead (Figure 7). Present results are a very strong confirmation, that not the intracellular citrate accumulation alone, however the active secretion of citrate over plasma membrane is the speed determining factor for citric acid excretion, displaying an optimum at $\mathrm{pH}$ 5. Highest extracellular citrate concentration was found under conditions, where the lowest total acid and glucose concentration occurred, as a result of intensive citrate secretion. A higher glucose uptake and glycolysis rate is proposed at optimum $\mathrm{pH} 5$.

\section{DISCUSSION}

Many reports exist related to the influence of initial or operating $\mathrm{pH}$ and other fermentation parameters on citric acid fermentation. Basically, most investigations were carried out in batch experiments running in stirrer fermenter or shake flasks (Nubel et al. 1971; Briffaud and Engasser, 1979; Kozlova et al. 1981; Lozinov and Finogenowa, 1982; Enzminger and Asenjo, 1986; Behrens et al. 1987; Rane and Sims, 1993; Antonucci et al. 2001; Crolla and Kennedy, 2001). However, no information was found about the influence of $\mathrm{pH}$ on the continuous citric acid secretion and a little is known regarding the real $\mathrm{pH}$ effect on citrate formation. Kinetic data obtained in chemostat cultures give essential information for sophisticated process design, process development and scale up. This type of information for continuous citric acid fermentation is rather rare in literature. For instance, looking in the internet about 15,200 results was found as compared with 89 for chemostat (Anastassiadis et al. 2004). Tisnadjaja et al. (1996) reported about a higher productivity of citric acid using $C$. guilliermondii in continuous culture compared with the batch process. About a four stage process for continuous production of citric acid using $A$. niger has been reported by Wieczorek and Brauer (1998).

The active citric acid export found for the first time in yeasts has been shown in present work to be a strongly $\mathrm{pH}$ 


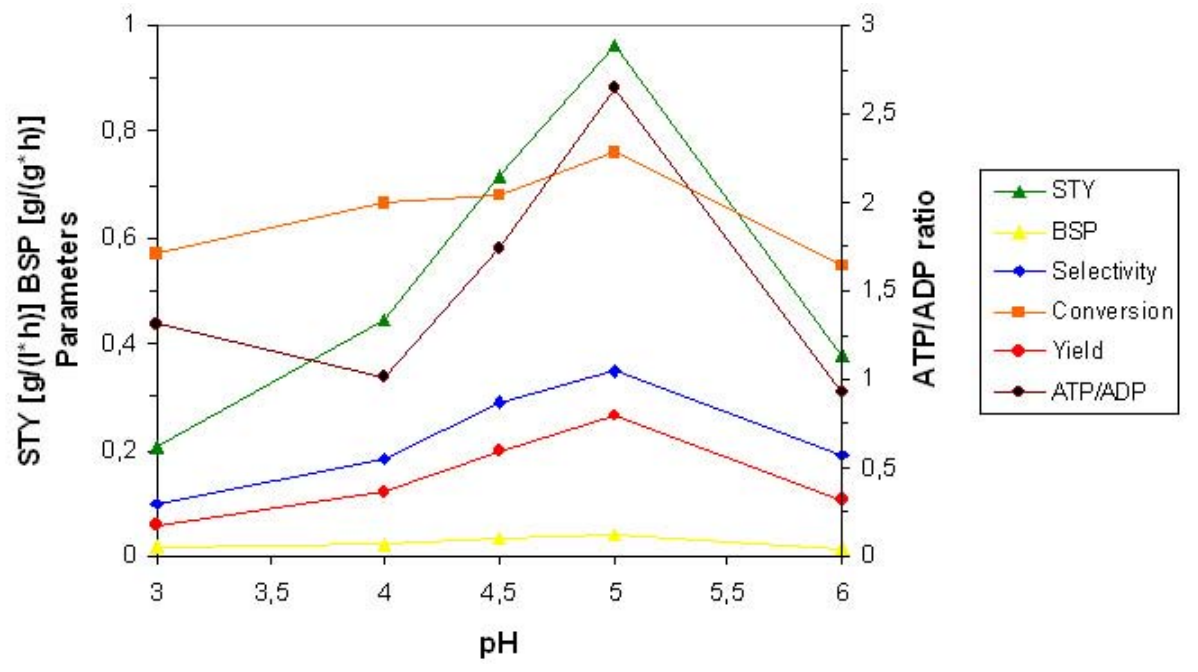

Figure 6. Influence of $\mathrm{pH}$ on STY, BSP, ATPIADP ratio and the specific parameters selectivity, conversion and yield $\left(4.5 \mathrm{~g} / \mathrm{N} \mathrm{NH}_{4} \mathrm{Cl}\right.$, $250 \mathrm{~g} / \mathrm{l}$ glucose and a residence time of $60 \mathrm{hrs}$ ).

dependent process. The $\mathrm{pH}$ had a remarkable effect on the growth, the elemental biomass composition and the secretion of citric acid in $C$. oleophila, displaying a production optimum and higher biomass iron content at $\mathrm{pH}$ 5. Already very low iron (cofactor of aconitase) concentrations $(<20 \mu \mathrm{M})$ affect dramatically citric acid formation and ratio between citrate and isocitrate. On the other side, Crolla and Kennedy (2001) reached highest citrate production in C. lipolytica using $10 \mathrm{mg} / 1$ ferric nitrate. Iron is essential for yeast growth, however a little is known about the mechanism of its assimilation. Shavloskii et al. (1988) identified an active iron uptake system in Pichia quilliermondii with an optimum at $\mathrm{pH} 5.3$ and $37^{\circ} \mathrm{C}$, whereas small $\mathrm{pH}$ alterations caused a dramatic lost of its uptake activity (90\%). Kamzolova et al. (2003) reported about the dependency of oxygen requirements for the growth of Y. lipolytica and of citric acid synthesis on iron concentration. Oexle et al. (1999) reported about the modulation of the expression of the critical citric acid cycle enzyme aconitase via a translational mechanism involving iron regulatory proteins in human cell lines and the iron effect on other citric acid cycle enzymes.

Most of published works regarding citric acid production by yeasts were performed at $\mathrm{pH}$ between 4.5 and 5.5 (Briffaud and Engasser, 1979: pH 4.7; Enzminger and Asenjo, 1986: pH 5.0; Klasson et al. 1989: pH 5.5; Grewal and Kalra, 1995: $\mathrm{pH}>5.5$; Anastassiadis et al. 2004). Nubel et al. (1971) reported on the other side about citric acid production in Candida (Yarrowia) lipolytica ATCC 20228, occurring even at lower $\mathrm{pH}$. The yeast process differs from Aspergillus niger in terms of optimum $\mathrm{pH}$ operation, where $\mathrm{pH}$ lower than 2 is necessary for optimum citric acid production (Rehm, 1980; Grewal and Kalra, 1995; Netik et al. 1997). An optimum $\mathrm{pH}$ of 1.7 has been reported for continuous citric acid fermentation by A. niger (Kristiansen and Charley, 1981). On the other side, Roukas and Harvey (1988) claimed an optimum $\mathrm{pH}$ of 4 for continuous citric acid production in A. niger. A sharp maximum around $\mathrm{pH}$ 3.4 has been found for continuous citric acid fermentation by A. foetidus (Kristiansen and Sinclair, 1979). Alternatively, Penicillium strains are producing citric acid at $\mathrm{pH}$ between 4 and 7 (Schinner and Burgstaller, 1989; Franz et al. 1991). Some variations in intracellular compartmentalization, $\mathrm{pH}$ topographies and differentiations in $\mathrm{pH}$ gradient (inside/outside) or regulation mechanisms may provide the explanation for those differences between various microbial systems. Roos and Slavik (1987) found two separate layers in cytoplasm of $P$. cyclopium (citrate producer), a thin outer layer with a $\mathrm{pH}$ of 5 and a greater core layer with approximate neutral $\mathrm{pH}$.

The lower citric acid production occurring at lower $\mathrm{pH}$ in yeasts could be theoretically attributed to reduced intracellular citrate formation or/and inhibition of citrate transport over the mitochondrial or cytoplasm membrane. Furthermore, citric acid secretion in yeasts has been reported to occur only as a result of passive diffusion of the undissociated acid through plasma membrane (Marchal et al. 1980; Netik et al. 1997). However, present results showed clearly that citrate secretion by the specific $\mathrm{pH}$ dependent active transport systemand not intracellular citrate accumulation alone is the crucial speed determining factor for overproduction in yeasts (Figure 8). The highest extra-/intracellular ratio of 6.8 for citrate and of 0.24 for isocitrate that have been determined at optimum $\mathrm{pH} 5$ revealed the high specificity of transport system for citrate over isocitrate. The difference between extra- and intracellular isocitrate concentration is lower than 1, indicating that it doesn't seem to be an affine substrate for the active transport system and a diffusive excretion of isocitrate into medium may also take place, forced by gradient imbalances. Netik et al. (1997) reported about an active secretion of citric acid in A. niger, explained by small gradient differences of slightly above 2 ( $42 \%$ in cells of A. niger) found between extra- and intracellular 


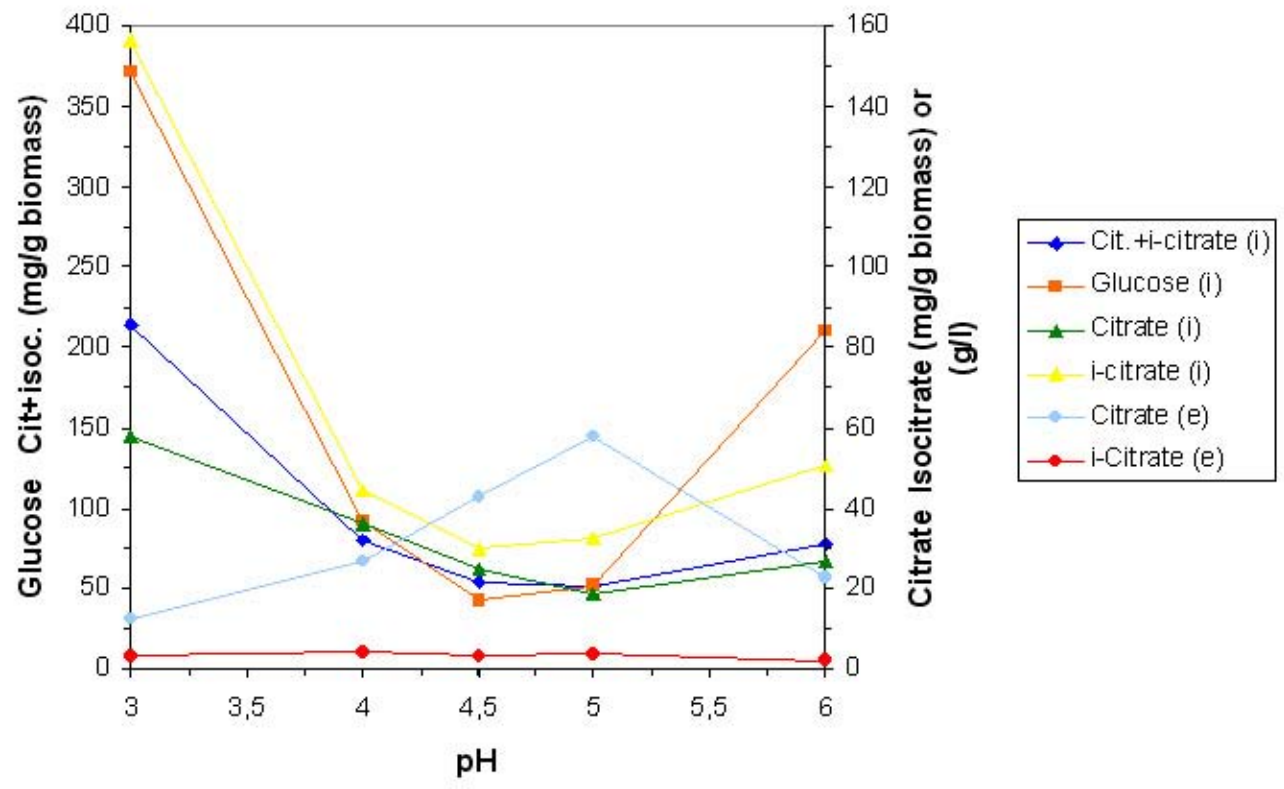

Figure 7. Intracellular concentrations $(\mathrm{g} / \mathrm{g})$ of citrate, isocitrate, total acid and glucose, compared with the extracellular concentration ( $\mathrm{g} / \mathrm{l})$ of citric and isocitric acid, as a function of $\mathrm{pH}\left(4.5 \mathrm{~g} / \mathrm{l} \mathrm{NH} \mathrm{Nl}_{4}, 250 \mathrm{~g} / \mathrm{l}\right.$ glucose and a residence time of $\left.60 \mathrm{hrs}\right)$.

concentrations of citric acid. A very high difference between extra- and intracellular citric acid concentration of about 60 has been calculated at citric acid concentration of $250 \mathrm{~g} / 1$ that has been achieved using $C$. oleophila and $Y$. lipolytica.

Intracellular accumulation and secretion of citrates are obviously two totally different phenomena, influencing each other, every time in a different way based on varying environmental conditions. Highest extracellular citrate concentrations were identified under optimised conditions (e.g. optimum air saturation, optimum temperature, optimum $\mathrm{pH}$, optimum concentrations of important trace elements), where under also the lowest intracellular concentrations of citrates were identified (Anastassiadis et al. 1993; Anastassiadis, 1994). Thus, the active transport system seems to be induced by other factors, either than by the intracellular accumulation of citric acid. However, a certain critical intracellular level of citrate $(\sim 20 \mathrm{mM})$, determined at optimum air saturation of $20 \%$, was found to be necessary for functioning of active transport system (Anastassiadis et al. 1993; Anastassiadis, 1994; Anastassiadis et al. 1994; Anastassiadis et al. 2001). Higher intracellular concentrations of citrates were also found in chemostat cultures of $C$. oleophila under non producing conditions at lower residence times, compared with higher producing residence times, confirming once again that citrate secretion by the specific energy consuming active transport system is the main speed determining event in citric acid overproduction (Anastassiadis et al. 1993; Anastassiadis, 1994), rather than intracellular citrate accumulation alone, as has been broadly thought before in international scientific community. Such transport systems are generally carrier proteins (Krämer and Sprenger, 1993).
Isocitric acid is taken out from aconitase equilibrium towards citric acid, followed up by citrate's secretion, resulting under optimum fermentation conditions to lowest intracellular concentrations of citric and isocitric acid. The lower biomass iron content found at $\mathrm{pH} 3$ would mean a lower aconitase activity. However, lower aconitase activity caused by iron deficiency wouldn't explain the 3-fold intracellular isocitrate concentration compared with citrate at $\mathrm{pH}$ 3. In order to understand citric acid production as an event of "over flow metabolism", it is essential to consider citric acid overproduction as a whole complex biological system, starting at the initial growth and ending with the active product secretion. Passive diffusion of citric acids at lower $\mathrm{pH}$-values seems hardly to be possible (citrate $\mathrm{pK}_{1}=$ $3.13, \mathrm{pK}_{2}=4.76$ and $\mathrm{pK}_{3}=6.40$; isocitrate $\mathrm{pK}_{1}=3.29, \mathrm{pK}_{2}$ $=4.71$ and $\left.\mathrm{pK}_{3}=6.40\right)$. Because the $\mathrm{pK}_{\mathrm{s}}$ values of citrate and isocitrate are almost identical, only the involvement of a transport system for citrate could explain the specificity of citrate over isocitrate. Cassio and Leao (1991) identified a low- (facilitated diffusion) and a high-affinity transport system (presumably a proton-citrate symport) for citrate uptake in yeast Candida utilis. Isocitrate competitively inhibited citrate uptake by the high-affinity system, suggesting that both of tricarboxylic acids used the same system (Cassio and Leao, 1991). An inducible uptake system for lactate with a $\mathrm{pH}$ optimum around 5 has been identified in Candida utilis by Leao and Van Uden (1986) as well.

The mechanism of citrate accumulation in yeasts has been studied for several years (Marchal et al. 1980; Gutierrez and Maddox, 1993; Anastassiadis, 1994; Netik et al. 1997; Anastassiadis et al. 2002). While transport of mitochondrial citrate and isocitrate into cytoplasm is well known, a little 
was known about excretion of citrate into culture medium. Vacuolisation of cytoplasm has also been discussed in connection with citrate production in C. lipolytica (Kozlova et al. 1981; Behrens et al. 1987). However, in case that citrate excretion would be mediated by vacuoles, specificity between excretion of citrate and isocitrate would be attributed to aconitase equilibrium. An argument against this hypothesis is the lower intracellular iron concentration that indicates lower aconitase activity and in the mean time the higher intracellular isocitrate concentration found in present work at $\mathrm{pH} 3$.

Marchal et al. (1980) and McKay et al. (cited in: Gutierrez and Maddox, 1993) proposed a passive diffusion of citrate and isocitrate over yeast plasma membrane into fermentation medium, in a ratio reflecting their intracellular equilibrium, and the existence of a selective transport of mitochondrial isocitrate to cytoplasm, based on intra- and extracellular concentrations of citrate found in experiments using C. lipolytica and paraffins as sole $\mathrm{C}$-source. The higher intracellular isocitrate concentrations indicate a high aconitase activity and in accordance to Marchal et al. (1980) a selective accumulation of isocitrate in cytoplasm. Citric acid production by yeasts seems to be a paradox, because cell accumulation of citric acid occurs under high ratio between ATP and ADP (Anastassiadis, 1994), although the process is considered to be non-growth related, triggered out by nitrogen limitation. The strong correlation found between ATP/ADP ratio and citric acid accumulation varying the $\mathrm{pH}$ can be considered as a consequence of a high glycolytic flow under nitrogen limitation and intracellular $\mathrm{NH}_{4}^{+}$accumulation. A relatively high intracellular $\mathrm{NH}_{4}^{+}$concentration of about $1.2 \mathrm{mg} / \mathrm{g}$ biomass $(\sim 37.4 \mathrm{mM})$ was found in C. oleophila during the production phase (Anastassiadis, 1994; Anastassiadis et al. 2002). The $\mathrm{pH}$ dependent specific active transport is providing the explanation for citrate overproduction in yeasts. Active transport seems to be a way for regenerating reduction equivalents and converting excessive ATP, gained by intensive glycolysis under growth limiting conditions.

Yeasts are divided in two categories, namely the lipogenous and non-lipogenous citric acid accumulating strains, which can also include strains of the same genera. Under nitrogen limitation, yeasts belonging to the first category predominantly form fatty acids from intracellular citric acid by ATP:citrate lyase (located in cytosol), whereas yeasts belonging to the latter category produce citric acid (Evans and Ratledge, 1985). Thus, fatty acid synthesis and citric

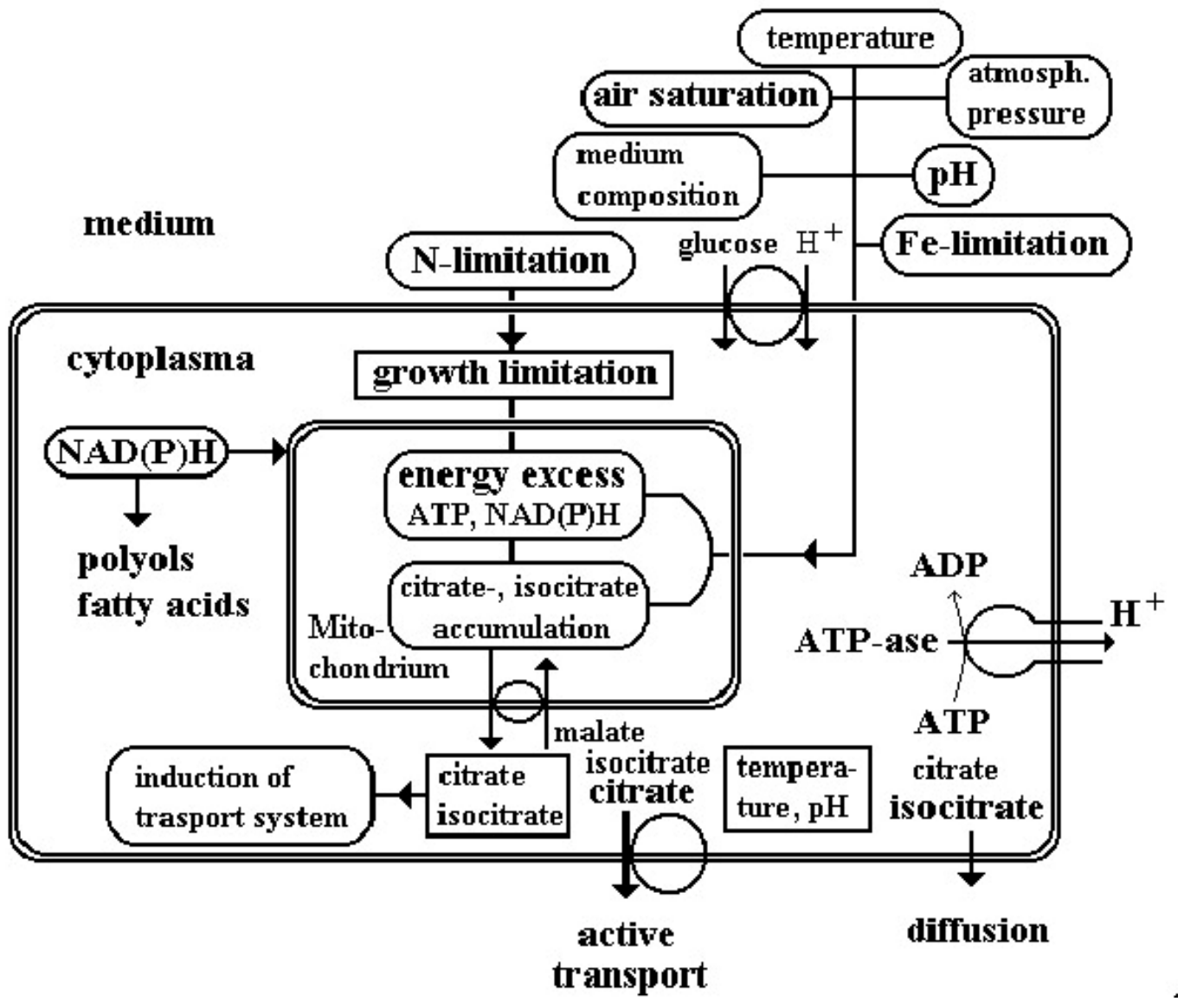

Figure 8. Proposed flow scheme of citric acid overproduction in yeasts based on experimental results obtained in chemostat cultures of $C$. oleophila and literature reports. 
acid secretion by active transport system can be considered as a means to cut down energy overload and surplus amount of $\mathrm{NAD}(\mathrm{P}) \mathrm{H}_{2}$. It seems also useful to consider polyol formation under the aspect of regulation, because polyol formation is discussed in relation to regeneration of reduced pyridine nucleotides in yeasts (Lozinov and Finogenova, 1982) as well as in Aspergillus niger (Röhr et al. 1987; Honecker et al. 1989; Wallrath et al. 1991).

The overproduction of precursors for di- and polysaccharide formation (e.g. trehalose, glycogen and pullulan) under various nutrient limitations by certain yeasts and moulds may be regulated by feedback control of an elevated cytosolic pool of citrate (Evans and Ratledge, 1985; Anastassiadis, 1994). The existence of active transport system for citrate secretion and the strong correlation between ATP/ADP ratio and citrate overproduction, found in C. oleophila, goes well together with reports of Lozinov and Finogenova (1982) about a non phosphorylating alternative oxidase, identified in yeasts, that completes electron flow without ATP regeneration, competing citrate production. Active citric acid producing strains showed lower alternative oxidase activity instead. Whether the energy charge is the driving force of citrate excretion in A. niger is still unclear. In contrast to yeasts an active non-phosphorylating alternative oxidase is discussed in relation to overproduction of citric acid in A. niger (Wallrath et al. 1991). In this case, reduction equivalents are regenerated by the alternative oxidase, rather than by ATP formation. Meyrath (1967) has discussed on the other side the energy demand for growth and citrate excretion in relation to citrate overproduction with not growing cells of $A$. niger. A significant amount of energy is required since the acid is excreted against a concentration gradient. Kristiansen and Sinclair (1979) proposed an other option explaining citrate production in $A$. niger under consideration of cytoplasm streaming.

\section{CONCLUDING REMARKS}

Citric acid production is obviously a very complicated process, whereby numerous events such as growth limitations, enzyme activities, energy gain and energy state, intracellular acid accumulation, as well as uptake and transport systems display different optima and regulation mechanisms, which are however somehow interconnected and interrelated in a synergistic mode. Essentially higher intracellular isocitrate concentrations found in producing cells of $C$. oleophila in comparison to citrate indicate a high aconitase activity. However, isocitrate doesn't seem to be a high-affine substrate for active transport system. Thus, the specific active transport of citrate is resulting to decreasing intracellular whole acid and cytoplasmatic isocitrate concentration under optimum fermentation conditions. This phenomenon is a further evidence for the existence of a specific active transport system for citrate secretion in yeasts, well explaining the overproduction of citric acid against a very strong concentration gradient. Figure 8 resumes most crucial evens influencing citric acid overproduction in yeasts.

\section{ACKNOWLEDGMENTS}

We thank Professor Dr. U. Stottmeister (UFZ Ctr. Envtl. Res. Leipzig-Halle, Germany), Prof. Dr. R. Krämer (Research Centre Jülich RCJ, Germany) and Prof. Dr. Christian Wandrey (Research Centre Jülich RCJ, Germany) for their helpful advices and support.

\section{REFERENCES}

AGRAWAL, P.K.; BHATT, C.S. and VISWANATHAN, L. Studies on some enzymes relevant to citric acid accumulation by Aspergillus niger. Enzyme and Microbial Technology, 1983, vol. 5, no. 5, p. 369-372.

ANASTASSIADIS, Savas, WANDREY, Christian and REHM, Hans-Jürgen. Continuous citric acid fermentation by Candida oleophila under nitrogen limitation at constant $\mathrm{C} / \mathrm{N}$ ratio. World Journal of Microbiology and Biotechnology (in press), 2005.

ANASTASSIADIS, Savas; AIVASIDIS, Alexander and WANDREY, Christian. Citric acid production by Candida strains under intracellular nitrogen limitation. Applied Microbiology Biotechnology, 2002, vol. 60, no. 1-2, p. 8187.

ANASTASSIADIS, Savas; AIVASIDIS, Alexander and WANDREY, Christian. Process for the continuous production of citric acid by fermentation. US Patent No. 08/208,123, August 3 1994, 2001.

ANASTASSIADIS, Savas. Zymotiki methodos gia tin sinechi paragogi tou kitrikou oxeos; Process for the continuous production of citric acid by fermentation. Greek Patent No. 940100098, February 24 1994, 1994.

ANASTASSIADIS, Savas. Determination of organic acids, especially citric acid and isocitric acid, in fermentation solutions and fruit juices. In: HPLC Applications, MACHEREY-NAGEL GmbH \& Co. KG, Düren, Germany. 1993, Application no. 8, p. 4.

ANASTASSIADIS, Savas; AIVASIDIS, Alexander and WANDREY, Christian. Fermentationsverfahren zur kontinuierlichen Citronensäuregewinnung(Process for the continuous production of citric acid by fermentation), German Patent No. P 4317 488.4-09, March 181993, 1993.

ANASTASSIADIS, Savas; AIVASIDIS, Alexander and WANDREY, Christian. Fermentationsverfahren zur kontinuierlichen Citronensäuregewinnung. (Process for the continuous production of citric acid by fermentation). Austrian Patent No. 473/94, July 3 1994, 1994. 
ANTONUCCI, S.; BRAVI, M.; BUBBICO R.; Di MICHELE, A. and VERDONE, N. Selectivity in citric acid production by Yarrowia lipolytica. Enzyme and Microbial Technology, 2001, vol. 28, no. 2-3, p. 189-195.

BEHRENS, U.; THIERSCH, A.; WEISSBRODT, E. and STOTTMEISTER, U. Particularities in the kinetics of growth and citric acid accumulation by Saccharomycopsis lipolytica. Acta Biotechnologica, 1987, vol. 7, no. 2, p. 179183.

BRIFFAUD, J. and ENGASSER, M. Citric acid production from glucose. I. Growth and excretion kinetics in a stirred fermentor. Biotechnology and Bioengineering, 1979, vol. 21, no. 11, p. 2082-2092.

CASSIO, F. and LEAO, C. Low- and high-affinity transport system for citric acid in the yeast Candida utilis. Applied and Environmental Microbiology, 1991, vol. 57, no. 12 , p. 3623-3628.

CROLLA, A. and KENNEDY, K.J. Fed-batch production of citric acid by Candida lipolytica grown on $n$-paraffins. Journal of Biotechnology, 2004, vol. 110, no. 1, p. 73-84.

CROLLA, A. and KENNEDY, K.J. Optimization of citric acid production from Candida lipolytica Y-1095 using nparaffin. Journal of Biotechnology, 2001, vol. 89, no. 1, p. $27-40$.

CRUEGER, W. and CRUEGER, A. Organische Säuren. In: Biotechnologie, Lehrbuch der angewandten Mikrobiologie, Oldenbourg Verlag GmbH, München, Wien, 1989, chapter 8, p. 127-141. ISBN 3-486-28403-7.

DAWSON, M.W. and MADDOX, I.S. Evidence for nitrogen catabolite repression during citric acid production by Aspergillus niger under phosphate-limited growth. Biotechnology and Bioengineering, 1989, vol. 33, no. 11, p. 1500-1504.

GREWAL, H.S and KALRA K.L. Fungal production of citric acid. Biotechnology Advances, 1995, vol. 13, no. 2, p. 209-234.

GUTIERREZ, N.A. and MADDOX, I.S. Evidence that impaired citrate transport into the cell is a contributory factor to extracellular citrate accumulation by a strain of Candida quilliermondii. Applied Microbiology and Biotechnology, 1993, vol. 39, no. 4-5, p. 604-608.

ENZMINGER, J.D. and ASENJO, J.A. Use of cell recycle in the aerobic fermentative production of citric acid by yeast. Biotechnology Letters, 1986, vol. 8, no. 1, p. 7-12.

EVANS, C.T. and RATLEDGE, C. The physiological significance of citric acid in the control of metabolism in lipid-accumulating yeasts. Biotechnology and Genetic Engineering Reviews (Hants), 1985, vol. 3, p. 349-375.
FRANZ, A.; BURGSTALLER, W. and SCHINNER F. Leaching with Penicillium simplissimum: Influence of metals and buffers on proton extrusion and citric acid production. Applied and Environmental Microbiology, 1991, vol. 57, no. 3, p. 769-774.

HABISON, A.; KUBICEK, C.P. and RÖHR, M. Partial purification and regulatory properties of phosphofructokinase from Aspergillus niger. Biochemical Journal, 1983, vol. 209, no. 3, p. 669-676.

HABISON, A.; KUBICEK, C.P. and RÖHR, M. Phosphofructokinase as a regulatory enzyme in citric acid producing Aspergillus niger. FEMS Microbiology Letters, 1979, vol. 5, no. 1 , p. 39-42.

HAQ, I.-U.; ALI, S.; QADEER, M.A. and IQBAL, J. Effect of copper ions on mould morphology and citric acid productivity by Aspergillus niger using molasses based media. Process Biochemistry, 2002, vol. 37, no. 10. p. 1085-1090.

HÖFER, M.; NICOLAY, K. and ROBILLARD, G. The electrochemical $\mathrm{H}^{+}$-Gradient in the yeast Rhodotorula glutinis. Journal of Bioenenergetics and Biomembranes, 1985, vol. 17, no. 3, p. 175-182.

HONECKER, S.; BISPING, B.; YANG, Z. and REHM, H.$\mathrm{J}$. Influence of sucrose concentration and phosphate limitation on citric acid production by immobilized cells of Aspergillus niger. Applied Microbiology and Biotechnology, 1989, vol. 31, p.17-24.

IKENO, Y.; MASUDA, M.; TANNO, K.; OOMORI, I. and TAKAHASHI, N. Citric acid production from various raw materials by yeasts. Journal of Fermentation Technology, 1975, vol. 53, no. 10, p. 752-756.

KAMZOLOVA, S.V.; SHISHKANOVA, N.V.; MORGUNOV, I.G. and FINOGENOVA, T.V. Oxygen requirements for growth and citric acid production of Yarrowia lipolytica. FEMS Yeast Research, 2003, vol. 3, no. 2, p. 217-222.

KAPOOR, K.K.; CHAUDHARY, K. and TAURO, P. Citric acid. In: REED, Gerald ed. Prescott and Dunn's Industrial Microbiology. $4^{\text {th }}$ ed., 1982, p. 709-742.

KISSER, M.; KUBICEK, C.P. and RÖHR, M. Influence of manganese on morphology and cell wall composition of Aspergillus niger during citric acid fermentation. Archives of Microbiology, 1980, vol. 128, no. 1, p. 26-33.

KLASSON, T.K.; CLAUSEN, E.C. and GADDY, J.C. Continuous fermentation for the production of citric acid from glucose. Applied Biochemistry and Biotechnology, 1989, vol. 20/21, p. 491-505.

KNOWLES, C.J. Microbial metabolic regulation by adenine nucleotide pools. In: HADDOCK, B.A. and 
HAMILTON, W.A. eds. Microbial Energetics. Cambridge University Press, Cambridge, 1977, p. 241-283.

KOZLOVA, T.M.; MEDVEDEVA, G.A.; GLAZUNOVA, L.M. and FINOGENOVA, T.V. Structural changes in the cells of Candida lipolylica in the biosynthesis of citric acid. Mikrobiologiya, 1981, vol. 50, no. 3, p. 508-514.

KRÄMER, R. and SPRENGER, G. Metabolism. In: SAHM, H. ed. BiotechnologyVol I; $2^{\text {nd }}$ REHM, H-J.; REED, G.; PÜHLER, A. and STADLER, P. eds. Weinheim, New York, Basel, Cambridge, Tokyo, 1993, pp. 641, ISBN 3-527-28311-0.

KRISTIANSEN, B.; CHARLEY, R.C.; SEVIOUR, B.; HARVEY, L.; HABEEB, S. and SMITH, J.E. Overproduction of metabolites by filamentous fungi. In: KRUMPHANZL, V.; SIKYTA, B. and VANEK, Z. eds. Overproduction of microbial products. Academic press, London, New York, Paris, San Diego, San Francisco, Sao Paulo, Sydney, Tokyo, Toronto, 1982, p. 195-210.

KRISTIANSEN, B. and CHARLEY, R.C. Continuous process for production of citric acid. Advances in Biotechnology, 1981, vol. 1, p. 221-227.

KRISTIANSEN, B. and SINCLAIR, C.G. Production of citric acid in continuous culture. Biotechnology and Bioengineering, 1979, vol. 21, no. 2, p. 297-315.

KUBICEK, C.P. and RÖHR, M. Citric acid fermentation. Critical Reviews in Biotechnology, 1986, vol. 3, no. 4, p. 331-373.

KUBICEK, C.P.; RÖHR, M. and MA, H. Influence of manganese deficiency on nucleic acid and protein synthesis in Aspergillus niger during citric acid accumulation. Third European Congress on Biotechnology vol. 2, Verlag Chemie, Munich, 1984, p. 23-28.

KUBICEK, C.P. and RÖHR, M. Regulation of citrate synthase from the citric acid accumulating fungus, Aspergillus niger. Biochimica et Biophysica ACTA/General Subjects (Amsterdam), 1980, vol. 615, no. 2, p. 449-457.

KUBICEK, C.P.; ZEHENNTGRUBER, O.; El-KALAK, H. and RÖHR, M. Regulation of citric acid production by oxygen: Effect of dissolved oxygen tension on adenylate levels and respiration. European Journal of Applied Microbiology and Biotechnology, 1980, vol. 9, p. 101-117.

KUBICEK, C.P. and RÖHR, M.The role of tricarboxylic acid cycle in citric acid accumulation by Aspergillus niger. European Journal of Applied Microbiology and Biotechnology, 1978, vol. 5, no. 3, p. 263-271.

LEAO, C. and Van UDEN, N. Transport of lactate and other short-chain monocarboxylates in the yeast Candida utilis. Applied Microbiology and Biotechnology, 1986, vol. 23, no. 5, p. 389-393.
LOZINOV, A.B. and FINOGENOVA, T.V. Einfluß der Limitation des Wachstums von Hefen auf den oxidativen Stoffwechsel und die Produktsynthese. Acta Biotechnologica, 1982, vol. 2, no. 4, p. 317-324.

LOZINOV, A.B.; FINOGENOVA T.V. and GLAZUNOVA L.M. Limitation of the growth of Candida lipolytica and some metabolites oversynthesis. Mikrobiologia, 1974, vol. 43, no. 5, p. 786-789.

LUNDIN, A.; RICKARDSON, A. and THORE, A. Continuous monitoring of ATP-converting reactions by purified firelly luciferase. Analytical Biochemistry, 1976, vol. 75 , no. 2, p. 611-620.

MANSFELD, Johanna; FÖRSTER, Michael; HOFFMANN Torsten; SCHELLENBERGER Alfred and DAUTZENBERG, Horst. Coimmobilization of Yarrowia lipolytica cells and invertase in polyelectrolyte complex microcapsules. Enzyme and Microbial Technology, 1995, vol. 17 , no. 1, p. 11-17.

MARCHAL, R.; METCHE, M. and VANDECASTEELE, J.P. Intracellular concentrations of citric and isocitric acids in cultures of the citric acid-excreting yeast Saccharomycopsis lipolytica grown on alkanes. Journal of General Microbiology, 1980, vol. 116, no. 2, p. 535-538.

MEIXNER-MONORI, B.; KUBICEK, C.P.; HABISON, A.; KUBICEK-PRANZ, E.M. and RÖHR, M. Presence and regulation of the $\alpha$-Ketoglutarate-Dehydrogenase multienzyme complex in the filamentous fungus Aspergillus niger. Journal of Bacteriology, 1985, vol. 161, no. 1, p. 265-271.

MEIXNER-MONORI, B.; KUBICEK, C.P. and RÖHR, M. Pyruvat-Kinase from Aspergillus niger. A regulatory enzyme in glycolysis? Canadian Journal of Microbiology, 1984, vol. 30, no. 1, p. 16-22.

MEYRATH, J. Citric acid production. Process Biochemistry, 1967, vol. 2, no. 56, p. 25-27.

MILSON, P.E. Organic acid fermentation, especially citric acid. Food Biotechnology, 1987, vol. 1, p. 273-307.

MILSON, P.E. and MEERS, J.L. Citric acid. The practice of biotechnology: Current commodity products. In: BLANCH, H.W.; DREW, S. and WANG, D.I.C. eds. Comprehensive Biotechnology vol. 3, Pergamon Press, Oxford, New York, Toronto, Sydney, Frankfurt, 1985, p. 665-680.

MORESI, M. Effect of glucose concentration on citric acid production by Yarrowia lipolytica. Journal of Chemical Technology and Biotechnology, 1994, vol. 60, no. 4, p. 387 395.

NETIK, A.; TORRES, N.V.; RIOL, J.-M. and KUBICEK, C.P. Uptake and export of citric acid by Aspergillus niger is 
reciprocally regulated by manganese ions. Biochimica et Biophysica Acta (BBA) - Biomembranes, 1997, vol. 132, no. 2, p. 287-294.

NOGUCHI, Y. and JOHNSON, M.J. Citric acid fermentation with sugarpurified chelating resin. Journal of Bacteriology, 1961, vol. 82, p. 538-541.

NUBEL, R.C.; FITTS, R.A. and FINDLAY, C.B. Verfahren zur Herstellung von Citronensäure. German Patent 2.050.361, Auslegeschrift 2050 361, 1971, Phizer Inc., New York.

OEXLE, H.; GNAIGER, E. and WEISS, G. Iron-dependent changes in cellular energy metabolism: influence on citric acid cycle and oxidative phosphorylation. Biochimica et Biophysica Acta, 1999, vol. 1413, no. 3, p. 99-107.

PAPAGIANNI, M.; MATTEY, M. and KRISTIANSEN, B. Hyphal vacuolation and fragmentation in batch and fedbatch cultures of Aspergillus niger and its relation to citric acid production. Process Biochemistry, 1999, vol. 35, no. 34, p. 359-366.

PAPANIKOLAOU, S. and AGGELIS, G. Lipid production by Yarrowia lipolytica growing on industrial glycerol in a single-stage continuous culture. Bioresource Technology, 2002, vol. 82, no. 1, p. 43-49.

PAUL, G.C.; PRIEDE, M.A. and THOMAS, C.R. Relationship between morphology and citric acid production in submerged Aspergillus niger fermentations. Biochemical Engineering Journal, 1999, vol. 3, no. 2, p.121-129.

PEKSEL, A.; TORRES, N.V.; LIU, J.; JUNEAU, G. and KUBICEK, C.P. ${ }^{13} \mathrm{C}-\mathrm{NMR}$ analysis of glucose metabolism during citric acid production by Aspergillus niger. Applied Microbiology and Biotechnology, 2002, vol. 58, no. 2, p. 157-163.

PERA, L.M. and CALLIERI, D.A. Influence of calcium on fungal growth and citric acid production during fermentation of a sugarcane molasses-based medium by a strain of Aspergillus niger. World Journal of Microbiology and Biotechnology, 1999, vol. 15, no. 5, p. 647-649.

RANE, Kishore D. and SIMS, KEVIN A. Production of citric acid by Candida lipolytica Y1095: Effect of glucose concentration on yield and productivity. Enyzme and Microbial Technology, 1993, vol. 15, no. 8, p. 646-651.

REHM, H.-J. Industrielle Mikrobiologie, 2. Aufl., Springer Verlag, Berlin, Heidelberg, New York, 1980.

RÖHR, M.; KUBICEK, C.P.; ZEHENNTGRUBER, O. and ORTHOFER, R. Accumulation and partial reconsumption of polyols during citric acid fermentation by Aspergillus niger. Applied Microbiology and Biotechnology, 1987, vol. 27, p. 235-239.
RÖHR, M.; KUBICEK C.P. and KOMINEK, J. Citric acid. In: REHM H-J.; REED, G. and DELWEG, G. eds. Biotechnology vol. 3, Verlag Chemie, Weinheim, Deerfield Beach/Florida, Basel, 1983, p. 419-454.

RÖHR, M. and KUBICEK, C.P. Regulatory aspects of citric acid fermentation by Aspergillus niger. Process Biochemistry, 1981, vol. 6-7, p. 34-37.

ROOS, W. and SLAVIK, J. Intracellular pH topography of Penicillium cyclopium protoplasts. Maintenance of $\Delta \mathrm{pH}$ by both passive and active mechanisms. Biochimica et Biophysica ACTA/General Subjects, 1987, vol. 899, no. 1, p. 67-75.

ROUKAS, T. and HARVEY, L. The effect of $\mathrm{pH}$ on production of citric and gluconic acid from beet molasses using continuous culture. Biotechnology Letters, 1988, vol. 10, no. 4, p. 289-294.

SCHIMZ, K.L.; RÜTTEN, B. and TRETTER, M. Determination of adenosine nucleotides with luciferin/luciferase from crude firelly lantern extract on a bioluminescence analyser. Advances in Biotechnology, 1981, vol. 1, p. 457-462.

SCHINNER, W. and BURGSTALLER, W. Extraction of zinc from industrial waste by a Penicillium sp. Applied and Environmental Microbiology, 1989, vol 55, no 5, p. 11531156.

SHAVLOSKII, G.M.; FEDOROVICH, D.V. and NAZARUK, M.I. Some properties of the iron transport system and regulation of its synthesis in Pichia quilliermondii. Mikrobiologiya, 1988, vol. 57, no. 1, p. 1520.

SHU, P. and JOHNSON, M.J. Citric acid production by submerged fermentation with Aspergillus niger. Industrial and Engineering Chemistry, 1948a, vol. 40, p. 1202-1204.

SHU, P. and JOHNSON, M.J. The interdependence of medium constituents in citric acid production by submerged fermentation. Journal of Bacteriology, 1948b, vol. 56, p. 577-585.

STOTTMEISTER, U. and HOPPE, K. Organische Genußsäuren. In: RUTTLOFF, H. ed. Lebensmittelbiotechnologie, Entwicklungen und Aspekte, 1. Aufl., Akademie Verlag, 1991, p. 516-547.

TISNADJAJA, Djadjat; GUTIERREZ, Noemi, A. and MADDOX, Ian S. Citric acid production in a bubblecolumn reactor using cells of the yeast Candida guilliermondii immobilized by adsorption onto sawdust. Enzyme and Microbial Technology, 1996, vol. 19, no. 5, p. 343-347.

VENTER, T.; KOCK, J.L.F.; BOTES, P.J.; SMIT, M.S.; HUGO, A. and JOSEPH, M. Acetate enhances citric acid 
production by Yarrowia lipolytica when grown on sunflower oil. Systematic and Applied Microbiology, 2004, vol. 27, no. 2, p. 135-138.

WALLRATH, J.; SCHMIDT, M. and WEISS, H. Concomitant loss of respiratory chain NADH:Ubiquinone reductase (complex I) and citric acid accumulation in Aspergillus niger. Applied Microbiology and Biotechnology, 1991, vol. 36, no. 1, p. 76-81.

WIECZOREK, S. and BRAUER H. Continuous production of citric acid with recirculation of the fermentation broth after product recovery, Part 2: Product recovery and recirculation of the fermentation broth. Bioprocess Engineering, 1998, vol. 18, no. 2, p. 75-77.

ZEHENTGRUBER, O.; KUBICEK, C.P. and RÖHR, M. Alternative respiration of Aspergillus niger. FEMS Microbiology Letters, 1980, vol. 8, no. 2, p. 71-74.

\section{DECLARATION}

The experiments of the present manuscript comply with the currant laws of the country Germany (Institute of Biotechnology 2 of Research Centre Jülich 2, RCJ; formerly known as Nuclear Research Centre Jülich, KFA) and Greece (Research in Biotechnology Co., Avgi/Sohos, 57002 Thessaloniki), where the experiments were performed. 